\title{
Social capital as a theoretical approach in Strategic Management
}

\section{El capital social como enfoque teórico en Dirección Estratégica}

\author{
BEATRIZ ORTIZ GARCÍA NAVAS ${ }^{1}$ \\ MARIO JAVIER DONATE MANZANARES ${ }^{2}$ \\ FÁtIMA GUADAMILLAS GÓMEZ ${ }^{1}$ \\ Universidad de Castilla La Mancha (España)
}

Recibido el 27 de abril de 2016, aceptado el 1 de octubre de 2018

Publicado online el 13 de marzo de 2019

$\mathrm{N}^{\circ}$ de clasificación JEL: L29

DOI: $10.5295 / \mathrm{cdg} .160646$ bo

\section{Resumen:}

El principal objetivo de este trabajo es mostrar la relevancia estratégica del capital social organizacional desde un punto de vista teórico. En los últimos años, la literatura académica relacionada con este concepto ha experimentado un notable crecimiento, reconociendo que el capital social es un elemento fundamental para que las empresas generen ventajas competitivas. Sin embargo, se podría afirmar que su desarrollo es todavía incipiente al existir multitud de discrepaciancias entre los investigadores acerca de su conceptuación, la medición de sus dimensiones o los efectos positivos o negativos que podría tener sobre otras variables. Por este motivo, tomando como referencia la definición y dimensiones propuestas por Nahapiet y Ghoshal (1998), se ha realizado una revisión de las investigaciones que, de manera empírica, han estudiado las relaciones entre el capital social y distintos tipos de resultados organizacionales. Igualmente, se exponen diferentes nexos teóricos encontrados entre el capital social y los principales enfoques en Dirección Estratégica como son Enfoque Basado en el Capital Intelectual, el Enfoque Basado en el Conocimiento, el Enfoque Basado en los Recursos y el Enfoque Basado en las Capacidades dinámicas. Se concluye que el capital social, como recurso basado en el conocimiento, podría permitir el acceso a otros recursos internos o externos, y que la creación de valor y la generación de ventajas competitivas de una empresa puede provenir de la combinación de ambos ámbitos. Así, futuros estudios deben encaminarse hacia la profundización y clarificación de este nexo estratégico.

Palabras clave:

Capital social organizacional, enfoque teórico, Dirección Estratégica.

1 Departamento de Administración de Empresas. Facultad de Ciencias Jurídicas y Sociales. Cobertizo San Pedro Mártir, s/n, 45071 Toledo (España).Beatriz.Ortiz@uclm.es; Fatima.Guadamillas@uclm.es

2 Departamento de Administración de Empresas. Facultad de Derecho y Ciencias Sociales. Ronda de Toledo, s/n. 13071 Ciudad Real (España). MarioJavier.Donate@uclm.es 


\begin{abstract}
:
The objective of this research paper is to investigate, from a theoretical point of view, the strategic relevance of social capital. In recent years, academic literature in this field has witnessed remarkable growth, recognizing social capital as a key element for companies, due to its contribution to the creation of competitive advantages. However, it might be said that its development is still emerging, given the number of discrepancies among researchers regarding its definition, measurement, and its positive or negative impact on other variables. For this reason, a set of empirical studies that show the social capital effect on diverse types of organizational results have been reviewed, taking as a reference the definition and dimensions proposed by Nahapiet and Ghoshal (1998). Additionally, different theoretical links between social capital and four related Strategic Management approaches are presented, such as the Intellectual Capital-Based View, the Knowledge-Based View, the Resource-Based View and the Dynamic Resource-Based View. A main conclusion drawn from this review is that social capital, being a knowledge-based resource, enables access to both internal and external resources and thus a firm's competitive advantage and, consequently, its value creation can be generated from the combination of both areas. Going in depth and clarifying this strategic linkage are thus a challenge to address in future studies.
\end{abstract}

\title{
Keywords:
}

Organizational social capital, theoretical approach, Strategic Management. 


\section{INTRODUCTION}

Social capital usually refers to the ability that an agent has to obtain profits from its network of contacts (Portes 1998). It provides a greater basis for relations between individuals and/or organizations, which includes aspects relating to shared norms, trust or participation in the achievement of common aims (Aghamirzaee et al. 2014). In this sense, a company can generate value by improving its competitiveness and its business results through the establishment of a network of strategic relationships (Blasco et al. 2010; Wang and Chen 2016).

The term social capital has acquired a profound relevance in multiple areas of study spanning the social sciences (e.g.: sociology, economic, political science, business, etcetera) throughout the last three decades (Blasco et al. 2010), both in its theoretical aspects as in its applied aspects (Gallo and Garrido 2009). On this matter, numerous researchers in the field of strategic management have recognized social capital as being a key element for companies, due to its contribution to the creation of competitive advantages (e.g., Nahapiet and Ghoshal 1998; Tsai and Ghoshal 1998; Adler and Kwon 2002; García and Parra 2008; Blasco et al. 2010; Wang and Chen 2016).

The academic literature related to social capital has experienced considerable growth in several disciplines and thematic areas since its inception in the 1980s, including Strategic Management. However, the lack of consensus among many researchers in this area is evident, both in their conceptualisation and in the measurement of its dimensions or their positive or negative effects on other variables (Gallo and Garrido 2009).

The present research paper shows the strategic importance of social capital from a theoretical point of view by focusing on the various positive aspects attributed to it, and taking as a reference point the research of Nahapiet and Ghoshal (1998) as being one of the most complete and widely accepted perspectives of the literature on this construct. Although a branch of the literature indicates that social capital can also present some relevant disadvantages with regard to organizational inertia, resistance to change and a decline in the transmission of new ideas (Inkpen and Tsang 2005), this research follows the line of those that consider it as a resource that can enable the generation of sustainable competitive advantages in companies (see e.g. Gulati et al. 2000). Accordingly, first, a review is made of those works that have carried out an empirical study of the relationships between social capital and different types of organizational-type results, linked to knowledge or related to innovation. As regards the selection of works, it was taken into account if these were included in publications with a high impact index, taking as a reference the Journal Citation Reports (JCR) quality index. Second, a review presents different theoretical links found between social capital and the main approaches to strategic management. These theoretical approaches are basically the Intellectual Capital-based view, the Knowledge-based view, the Resource-based view and the Dynamic Capabilities-based view, always understanding that the scope encompassed by social capital is a very broad one and incorporates its own aspects and others that come from other disciplines related to the Social Sciences.

In this sense, it is considered that social capital is nourished by certain aspects of these perspectives that basically explain the creation of value from the acquisition/development/ construction of resources, assets, capabilities or unique and valuable knowledge. In this way, social capital may enable access to these resources, even when these are outside of the 
limits of the organization and then the competitive advantage of a company can come from the combination of the internal and external fields covered by this concept.

The research paper is structured as follows. In the first place, the research will be contextualized, justifying the choice of the definition and dimensions of the social capital that were adopted. Then, the most important strategic implications of its application will be reviewed, bearing in mind research work that has approached this topic from an empirical point of view. To conclude, those aspects of social capital that are linked to some of the main theories on Strategic Management will be analysed.

\section{SOCIAL CAPITAL: CONCEPT AND DIMENSIONS}

The Social capital notion was initially used to describe the relational resources included in cross-personal links useful for encouraging the development of individuals in organised social communities (Jacobs 1961; Loury 1977). Social capital theory has been exclusively applied to human beings and their "environment", until a few years ago (Bourdieu and Wacquant 1992). However, its study has been extended to the corporate field, considering firms as economic agents within their surrounding social structure (Moran and Ghoshal 1996). In this field, social capital definitions are very similar, although some nuances enable their differentiation and classification into three different approaches: internal, external and neutral (Adler and Kwon 2002; Delgado et al. 2011). At the same time, this distinction enables the concept be considered for analysis on different levels: individual or group (intra-organizational), and inter-firm (inter-organizational).

Considering the internal approach, social capital is principally developed through links between company's agents -shareholders, employees, executives, etcetera- or groups -strategic business units, divisions, departments, etcetera-, which have common problems and interests (community), thereby facilitating the search for the resolution of such problems (Adler and Kwon 2002). This kind of social capital is shared by, and available to, all groups of firms and individuals (Leana and Pil 2006).

Furthermore, from an external point of view, social capital is understood as being the set of direct and indirect relationships that an actor has with others actors, outside of the established bounds of the organizational community (Adler and Kwon 2002). According to Lesser (2000), external social capital is the set of relationships that a firm has with other agents when occupying a specific position on its business environment, thus allowing it to identify and transfer valuable resources beyond its borders. Moreover, such relationships can be both formal and informal (Nahapiet and Ghoshal 1998; Bolino et al. 2002; Zheng 2010; Martín-Rios and Septiem 2013), depending on whether there exists a contractual agreement as origin of the exchange (Granovetter 1992; Uzzi 1997).

Finally, the neutral perspective gathers in the same approach the internal and external social capital perspectives (Loury 1992; Nahapiet and Ghoshal 1998; Adler and Kwon 2002; Delgado et al. 2011). Adler and Kwon (2002) point out that the differences between the internal and external approach are frequently a matter of focus, with neither of them being mutually exclusive. In that sense, company behaviour is influenced by both its external links with other agents and its internal links structure. Therefore, the differences regarding property, use and benefits derived from social capital will be defined by the reasons why a 
firm designs a specific configuration of both types of social capital and by its community bounds (Blasco et al. 2010).

This research paper considers that Nahapiet and Ghoshal's (1998) approach, which has been described as neutral (Adler and Kwon 2002), is the most complete to explain the social capital construct. In recent years, their consideration of social capital has been the most widely accepted to explain from a strategic point of view the way that resources and capabilities are strategically exchanged between agents in a network. On the one hand, it allows social capital to be identified as a multidimensional construct that consolidates the value creation by resources and capabilities exchange between the different agents who are part of the same network. On the other hand, it makes it possible to consider a company's relationships with agents beyond its organizational borders -inter-organizational social capital- and the links between its members -intra-organizational social capital-. Hence, social capital is established as "the sum of the actual and potential resources embedded within, available through, and derived from the network of relationships possessed by an individual or social unit" (Nahapiet and Ghoshal 1998, p. 243).

In addition, the dimensions suggested by these authors -structural, relational and cognitive- seems to summarise all the aspects that underpin social capital as a valuable resource to firms because it is capable of providing rents, both Ricardian (those that are gained because of the possession or control of unique resources), and specifically relational (Nahapiet and Ghoshal 1998). Consequently, this is the most commonly used dimensional differentiation in social capital literature (Zheng 2010; Hsu and Hung 2013) for the purposes of examining its impact on issues such as organizational results (Leana and Pil 2006; Andrews 2010; Hsu and Hung 2013), knowledge acquisition and transfer (Presutti et al. 2007; Preston et al. 2017) or innovation (Tsai and Ghoshal 1998; Zheng 2010; Delgado et al. 2011).

Structural dimension represents the global combination of an agent's relationships in a network (Granovetter 1992; Nahapiet and Ghoshal 1998), and is defined by all the interaction features, which appear between each agent present in the network (Burt 1992). For this dimension, network density, stability over time, and the type of agent connection in terms of more or less strength, frequency and closeness are very important (Inkpen and Tsang 2005).

Furthermore, the relational dimension is related to the assets arising from the relation and interaction themselves, such as trust or integrity. The positive interactions between individuals or organizations over time as sources of social capital, are considered in this dimension (Lesser 2000). In that sense, the relational dimension is, on the one hand, based on general reciprocity rules (Putnam 1993), whereby an agent will do something for another according to a future return expectative. On the other hand, obligations are also an important aspect in this dimension, understood as the commitment or duty to undertake some activity in the future when a relationships is based on trust (Nahapiet and Ghoshal 1998).

Lastly, the cognitive dimension refers to shared codes that ease the mutual understanding of goals and behaviours in a social system (Tsai and Ghoshal 1998; Blasco et al. 2010). It has its origin in the agents' ability to develop a common language that allows an effective knowledge exchange (Nahapiet and Ghoshal 1998). The main aspects for defining this dimension are common goals and shared culture. According to Inkpen and Tsang (2005), common goals act as mechanisms for union, representing the degree to which network 
members share common understanding and shared visions. Furthermore, shared culture represents the rules system and the institutional standards that indicate a suitable behaviour for the network (Gulati et al. 2000; Inkpen and Tsan 2005).

Once the research theoretical position regarding social capital and its dimensions has been established, a wide range of empirical studies that highlight its strategic relevance as a source of competitive advantages will be reviewed.

\section{RESULTS FROM THE STRATEGIC MANAGEMENT OF SOCIAL CAPITAL}

Several studies have shown the influence of organizational social capital on a number of different types of variables, such as business performance -e.g. performance indicators, economic growth indicators, market share or increased sales-, diverse fields of knowledge management -e.g. knowledge identification, acquisition or transfer-, or innovation capability and results -e.g. new technologies generation-.

Regarding the business performance variable, the reviewed literature supports the relationship between social capital and different organizational outputs (e.g., Andrews 2010; Hsu and Hung 2013; Wang and Chen 2016, Bellavitis et al. 2017). For instance, Hsu and Hung (2013), in an information system development context, conclude that each social capital dimension -structural, relational and cognitive-, and their peer interaction, have a positive impact on both performance and systems development processes. Similarly, Wang and Chen (2016) show different influences that diverse network structures have on the business performance of start-ups, measured through their annual sales. Table 1 provides a summary of some of the studies reviewed that have evaluated this relationship along with their conclusions.

Table 1

Summary of studies regarding the social capital effect on business performance

\begin{tabular}{ccccc}
\hline Study & Sample & Context & $\begin{array}{c}\text { Social capital } \\
\text { dimensions }\end{array}$ & Type of results \\
\hline $\begin{array}{c}\text { Rowley, } \\
\text { Behrens and } \\
\text { Krackhardt } \\
(\mathbf{2 0 0 0 )}\end{array}$ & $\begin{array}{c}138 \text { firms from metal industry } \\
\text { and } 132 \text { from semiconductor } \\
\text { industry }\end{array}$ & $\begin{array}{c}\text { Strategic } \\
\text { alliances }\end{array}$ & $\begin{array}{c}\text { Structural } \\
\text { Relational }\end{array}$ & $\begin{array}{c}\text { ROA (return on } \\
\text { assets) }\end{array}$ \\
\hline
\end{tabular}

Conclusions: In both industries, strong and weak links are positively related to performance

Andrews

(2010)
100 public sector organizations
Inter-organizational
Structural

Relational Service performance

Conclusions: Relational and cognitive social capital dimensions are positively related to service performance, while structural dimension is not 


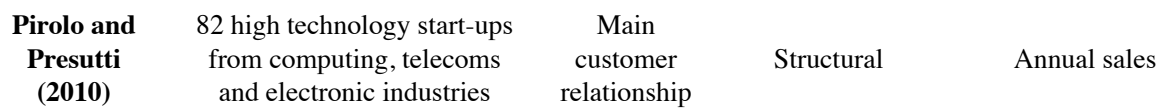

Conclusions: There is a positive impact of both strong and weak links on performance over the entire life-cycle of a company

\begin{tabular}{|c|c|c|c|c|}
\hline $\begin{array}{c}\text { Hsu and } \\
\text { Hung (2013) }\end{array}$ & $\begin{array}{l}240 \text { profes- } \\
\text { sionals in } \\
\text { information } \\
\text { system deve- } \\
\text { lopment in } \\
\text { companies } \\
\text { from Taiwan }\end{array}$ & Intra-organizational & $\begin{array}{l}\text { Structural } \\
\text { Relational } \\
\text { Cognitive }\end{array}$ & $\begin{array}{l}\text { Process performance } \\
\text { and success of } \\
\text { information system } \\
\text { development }\end{array}$ \\
\hline \multicolumn{5}{|c|}{$\begin{array}{l}\text { Conclusions: Social capital dimensions and their peer interaction have a positive influence on perfor- } \\
\text { mance, and information systems development process }\end{array}$} \\
\hline $\begin{array}{c}\text { Wang and } \\
\text { Cheng (2016) }\end{array}$ & $189 \mathrm{st}$ & $\begin{array}{l}\text { Cooperation } \\
\text { agreements }\end{array}$ & Structural & Annual sales \\
\hline \multicolumn{5}{|c|}{$\begin{array}{l}\text { Conclusions: Business performance is maximised through an optimal number of cooperation agreements } \\
\text { In addition, while centrality has a positive influence on performance, interaction strength exerts a negative } \\
\text { influence }\end{array}$} \\
\hline $\begin{array}{c}\text { Bellavitis, } \\
\text { Filatotchev } \\
\text { and Souitaris } \\
(\mathbf{2 0 1 7})\end{array}$ & $\begin{array}{l}427 \\
\text { capital risk } \\
\text { companies } \\
\text { from United } \\
\text { Kingdom }\end{array}$ & Capital risk consortium & Structural & Annual sales \\
\hline
\end{tabular}

Conclusions: Being a member of a cohesive network improves business performance of younger capital risk companies. However, once they move to maturity, having a position in an structural-hole network is associated with a greater performance

Source: Prepared by the authors.

Moreover, social capital researchers have identified knowledge access as a key benefit arising from its management (Inkpen and Tsang 2005). Social capital thus enables organizations to harness knowledge, sometimes tacit, from their network agents (Yli-Renko et al. 2001), and improves their ability to recognise and evaluate that knowledge (Dyer and Singh 1998; Smith et al. 2005). Similarly, it eases knowledge acquisition (Nahapiet and Ghoshal 1998; Adler and Kwon 2002; Parra et al. 2010), and its transfer both within (Maurer et al. 2011) and outside the organizational bounders (Lefebvrea et al. 2016; Preston et al. 2017). Moreover, social capital increases the opportunity to assimilate, transform and exploit knowledge effectively (Ebers and Maurer 2014). In this sense, many empirical studies have shown the relationship between organizational social capital and various as- 
pects related to both knowledge management and the knowledge absorption process. Table 2 summarises the main aspects included in some of these investigations.

Table 2

Summary of studies regarding the social capital effect on knowledge processes

\begin{tabular}{ccccc}
\hline Study & Sample & Context & $\begin{array}{c}\text { Social capital dimen- } \\
\text { sions }\end{array}$ & $\begin{array}{c}\text { Knowledge } \\
\text { process }\end{array}$ \\
\hline $\begin{array}{c}\text { Yli-Renko, Auto } \\
\text { and Sapienza } \\
(\mathbf{2 0 0 1 )}\end{array}$ & $\begin{array}{c}180 \text { young firms from } \\
\text { United Kingdom's } \\
\text { high-tech sectors }\end{array}$ & $\begin{array}{c}\text { Firm-main client } \\
\text { relationship }\end{array}$ & $\begin{array}{c}\text { Structural } \\
\text { Relational } \\
\text { Cognitive }\end{array}$ & $\begin{array}{c}\text { Knowledge } \\
\text { acquisition }\end{array}$ \\
\hline
\end{tabular}

Conclusions: Social interaction (relational component) and network ties (structural component) are positively related to knowledge acquisition. Nevertheless, relation quality (cognitive component) has a negative influence on acquisition

\begin{tabular}{ccccc}
\hline $\begin{array}{c}\text { Maula, Autio and } \\
\text { Murray (2003) }\end{array}$ & $\begin{array}{c}\text { 135 start-ups from } \\
\text { several high-tech } \\
\text { sectors }\end{array}$ & $\begin{array}{c}\text { Relationships with } \\
\text { venture capital } \\
\text { companies }\end{array}$ & Structural & $\begin{array}{c}\text { Knowledge } \\
\text { acquisition }\end{array}$ \\
\hline
\end{tabular}

Conclusions: Social interaction has a positive high influence on acquired knowledge level from investors relationships

\begin{tabular}{|c|c|c|c|c|}
\hline $\begin{array}{l}\text { Smith, Collins and } \\
\text { Clark (2005) }\end{array}$ & $\begin{array}{l}72 \text { technological } \\
\text { companies }\end{array}$ & $\begin{array}{l}\text { Intra-organizational } \\
\text { relationships }\end{array}$ & Structural & $\begin{array}{c}\text { Valuable } \\
\text { knowledge } \\
\text { identification }\end{array}$ \\
\hline
\end{tabular}

Conclusions: The strength of ties between network members influences positively on their ability to access groups or people with specialised knowledge, allowing the assimilation of the exchanged information and anticipation of the exchange value

\begin{tabular}{ccccc}
\hline $\begin{array}{c}\text { Collins and Smith } \\
\text { (2006) }\end{array}$ & $\begin{array}{c}136 \text { technological } \\
\text { companies }\end{array}$ & $\begin{array}{c}\text { Intra-organizational } \\
\text { relationships }\end{array}$ & $\begin{array}{c}\text { Relational } \\
\text { Cognitive }\end{array}$ & $\begin{array}{c}\text { Knowledge } \\
\text { transfer }\end{array}$ \\
\hline
\end{tabular}

Conclusions: Each social capital dimension has significantly positive effects on firm's profits and sales by means of its influence on knowledge combination and exchange

\begin{tabular}{|c|c|c|c|c|}
\hline $\begin{array}{l}\text { Presutti, Boari } \\
\text { and Fratocchi } \\
\qquad(2007)\end{array}$ & $\begin{array}{c}130 \text { high-tech start- } \\
\text { ups }\end{array}$ & $\begin{array}{c}\text { Relationships with } \\
\text { the main foreign } \\
\text { client }\end{array}$ & $\begin{array}{l}\text { Structural } \\
\text { Relational } \\
\text { Cognitive }\end{array}$ & $\begin{array}{l}\text { Knowledge } \\
\text { acquisition }\end{array}$ \\
\hline
\end{tabular}

Conclusions: Only the structural dimension of social capital, based on weak ties, has an influence on knowledge acquisition

\begin{tabular}{|c|c|c|c|c|}
\hline $\begin{array}{l}\text { Parra, Molina and } \\
\text { García }(\mathbf{2 0 1 0})\end{array}$ & $\begin{array}{l}224 \text { Spanish firms } \\
\text { from footwear } \\
\text { industry }\end{array}$ & Cluster & Cognitive & $\begin{array}{l}\text { Knowledge } \\
\text { acquisition }\end{array}$ \\
\hline
\end{tabular}

Conclusions: Shared goals and culture have an essential role in knowledge acquisition, having a positive effect on it 


\section{Maurer, Bartsch and Ebers (2011)}

218 projects of 144 firms from German mechanical engineering industry

$\begin{array}{ccc}\begin{array}{c}\text { Intra-organizational } \\ \text { relationships }\end{array} & \begin{array}{c}\text { Structural } \\ \text { Relational }\end{array} & \begin{array}{c}\text { Knowledge } \\ \text { mobilization } \\ \text { and use }\end{array}\end{array}$

Conclusions: Only the strength of ties (structural dimension) influences positively on knowledge mobilization, assimilation and use

\begin{tabular}{|c|c|c|c|c|}
\hline $\begin{array}{l}\text { Ebers and Maurer } \\
\text { (2014) }\end{array}$ & $\begin{array}{l}218 \text { projects of } 144 \\
\text { firms from German } \\
\text { mechanical engineer- } \\
\text { ing industry }\end{array}$ & $\begin{array}{l}\text { Intra/inter-organi- } \\
\text { zational relation- } \\
\text { ships }\end{array}$ & $\begin{array}{l}\text { Rela- } \\
\text { tional }\end{array}$ & $\begin{array}{c}\text { Potential } \\
\text { absorptive } \\
\text { capacity } \\
\text { Realized } \\
\text { absorptive } \\
\text { capacity }\end{array}$ \\
\hline
\end{tabular}

Conclusions: Gatekeeper's relational embedding is positively associated to its company's potential absorptive capacity, while its effect on realized absorptive capacity, although positive, is not very significant
Zhou, Zhang,
Sheng, Xie and
Bao (2014)
385 Chinese manufac- turing firms
Supplier-custo-
mer relationships
Relational
Knowledge acquisition

Conclusions: The dependency between a customer's relational ties and their main supplier, and specific knowledge acquisition has an inverted U-shape. Similarly, the U curvature is most pronounced the more specific the knowledge is

\begin{tabular}{|c|c|c|c|c|}
\hline $\begin{array}{l}\text { Lefebvrea, Soren- } \\
\text { son, Henchion and } \\
\text { Gellyncka (2016) }\end{array}$ & $\begin{array}{c}150 \text { members of } 16 \\
\text { European learning } \\
\text { networks }\end{array}$ & $\begin{array}{l}\text { Inter-organizational } \\
\text { networks within } \\
\text { each network }\end{array}$ & $\begin{array}{l}\text { Structural } \\
\text { Relational } \\
\text { Cognitive }\end{array}$ & $\begin{array}{l}\text { Knowledge } \\
\text { exchange }\end{array}$ \\
\hline
\end{tabular}

Conclusions: There is a positive relationship between structural social capital and knowledge exchange in learning networks. Moreover, structural social capital plays a significant role in cognitive social capital development within networks

\begin{tabular}{ccccc}
\hline $\begin{array}{c}\text { Preston, Chen, } \\
\text { Swink and Meade } \\
\text { (2017) }\end{array}$ & $\begin{array}{c}\text { 166 suppliers of the } \\
\text { main electronic compo- } \\
\text { nents distributor from } \\
\text { North America }\end{array}$ & $\begin{array}{c}\text { Supplier-custo- } \\
\text { mer relationships }\end{array}$ & $\begin{array}{c}\text { Structural } \\
\text { Relational } \\
\text { Cognitive }\end{array}$ & $\begin{array}{c}\text { Knowledge } \\
\text { transfer }\end{array}$ \\
\hline
\end{tabular}

Conclusions: Relational social capital, influenced by structural and cognitive social capital, has a significant and positive influence on knowledge transfer from customer to supplier

Source: Prepared by the authors.

Finally, with regard to innovation, the social capital approach has an interesting perception on how the effects of inter and intra-organizational relationships on this variable can be explained (Subramaniam and Youndt 2005; Zheng 2010), in terms of change extent, novelty, or innovation abilities development (Gatignon et al. 2002). In this regard, social capital literature suggests that, in addition to the number links and the network structure, a 
level of commitment, cohesion, trust (Adler and Kwon 2002; Mu et al. 2008), behavioural rules and shared goals (Doh and Acs 2010; Alarcón et al. 2014) in organizational relationships are also necessary in order to be innovative. Consequently, relationships with other agents are an essential factor for innovation processes, facilitating access to new sources of value creation through the acquisition of new resources based on knowledge, and their integration and combination with the company's own resources by means of its absorptive capacity (Cohen and Levinthal 1990; Moran and Ghoshal 1996). Several studies have shown the influence of social capital on innovation. Some of the most relevant are reflected in Table 3, according to their publication impact factor.

Table 3

Summary of studies regarding the social capital effect on innovation

\begin{tabular}{ccccc}
\hline Study & Sample & Context & $\begin{array}{c}\text { Social } \\
\text { capital } \\
\text { dimensions }\end{array}$ & Innovation type \\
\hline Landry, Amara and Lamari & $\begin{array}{c}\text { (2002) } \\
\text { from Montreal }\end{array}$ & $\begin{array}{c}\text { Relationships } \\
\text { with customers, } \\
\text { suppliers and } \\
\text { government }\end{array}$ & $\begin{array}{c}\text { Structural } \\
\text { Relational }\end{array}$ & $\begin{array}{c}\text { Innovation decision } \\
\text { Innovation radi- } \\
\text { calness }\end{array}$ \\
\hline
\end{tabular}

Conclusions: Both the strength of ties (structural dimension) and trust (relational dimension) exert an influence on both innovation decision and radicalness

\begin{tabular}{|c|c|c|c|c|}
\hline Dakhly and De Clercq (2004) & $\begin{array}{l}59 \text { countries } \\
\text { from database } \\
\text { "World Values } \\
\text { Survey" }\end{array}$ & National & $\begin{array}{l}\text { Structural } \\
\text { Relational } \\
\text { Cognitive }\end{array}$ & $\begin{array}{c}\text { Number of patents } \\
\text { R\&D expenditure } \\
\text { High-tech export } \\
\text { volume }\end{array}$ \\
\hline
\end{tabular}

Conclusions: Among all considered social capital aspects, trust (relational dimension) is the most significant for innovation, because it eases knowledge exchange and promotes cooperation, essential for R\&D activity development

$\begin{array}{cccc} & 120 \text { sales } & & \\ \text { Managers from a } & \text { Intra-organiza- } & \text { Structural } & \text { Executives' innova- } \\ \text { pharmaceutical } & \text { tional relation- } & \text { Relational } & \text { tive performance } \\ \text { Company with } & \text { ships } & & \\ & & & \end{array}$

Conclusions: The relational dimension plays a more significant role than the structural dimension for improving managerial performance towards innovation

$\begin{array}{ccccc} & & & \\ \text { Delgado, Martín, Navas and } & & & \\ \text { Cruz (2011) } & \begin{array}{c}1.270 \text { Spanish } \\ \text { firms from high- } \\ \text { and medium- } \\ \text { tech manufactur- } \\ \text { ing industry }\end{array} & \begin{array}{c}\text { Intra-organiza- } \\ \text { tional relation- } \\ \text { ships }\end{array} & \begin{array}{c}\text { Structural } \\ \text { Relational } \\ \text { Cognitive }\end{array} & \text { Product innovation } \\ & & & \\ \end{array}$

Conclusions: The three social capital dimensions have a significant positive effect on product innovation development. However, results show that shared vision (cognitive dimension) has a higher impact and explanatory power on that variable 


\begin{tabular}{lcccc}
\hline & & & & \\
Tsai, Joe, Ding y Lin (2013) & 302 IT compa- & Buyer-supplier & Structural & Technological \\
& nies' teams from & business- & To-business & Relational \\
Taiwan & relationships & Cognitive & innovation
\end{tabular}

Conclusions: Technological innovation is positively influenced by shared rules (cognitive dimension) and trust (relational dimension), through customers' knowledge development. Similarly, innovation performance is also positively affected by social interaction (structural dimension) and shared rules by means of innovation commitment

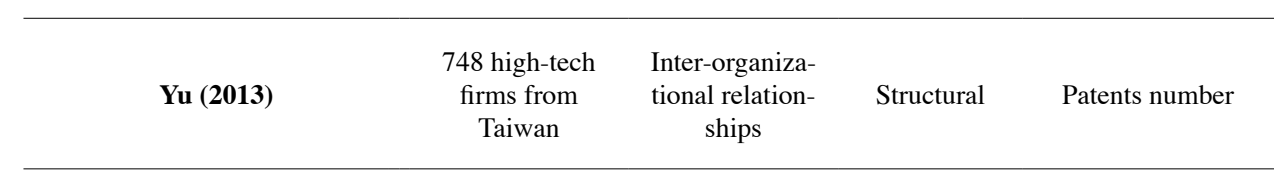

Conclusions: The relationship between the diversity of network-ties and innovation results has an inverted U-shape. A moderate level of network diversity can thus lead to the attainment of greater levels of innovation

\begin{tabular}{|c|c|c|c|c|}
\hline $\begin{array}{c}\text { Bellamy, Ghosh and Hora } \\
\text { (2014) }\end{array}$ & $\begin{array}{l}390 \text { firms form } \\
\text { electronic } \\
\text { industry }\end{array}$ & $\begin{array}{l}\text { Relations with } \\
\text { suppliers }\end{array}$ & Structural & Patents number \\
\hline \multicolumn{5}{|c|}{$\begin{array}{l}\text { Conclusions: The connection between supply network ties and accessibility to them significantly influen- } \\
\text { ces innovation results, as well as the interaction between the two variables. Additionally, that influence can be } \\
\text { improved by network absorptive and innovation capacity }\end{array}$} \\
\hline $\begin{array}{l}\text { Sanchez-Famoso, Maseda } \\
\text { and Iturralde (2017) }\end{array}$ & $\begin{array}{l}172 \text { Spanish } \\
\text { SMEs }\end{array}$ & $\begin{array}{l}\text { Intra-organiza- } \\
\text { tional relation- } \\
\quad \text { ships }\end{array}$ & $\begin{array}{l}\text { Structural } \\
\text { Relational } \\
\text { Cognitive }\end{array}$ & $\begin{array}{l}\text { Product/ service } \\
\text { innovation }\end{array}$ \\
\hline
\end{tabular}

Conclusions: Family management involvement has a negative and significant effect on the relationship between internal social capital and innovation

Source: Prepared by the authors.

\section{SOCIAL CAPITAL AND INTERNAL APPROACHES TO STRATEGIC MANAGEMENT}

In the previous sections it has been explained that organizational social capital (OSC) is a well-known concept that has been studied in different disciplines (e.g., organizational learning, networks studies, organizational behaviour, knowledge management) and it can be understood from diverse perspectives -internal, external, neutral-, different levels of analysis -individual, groups, inter-firm- (Tsai and Ghoshal 1998; Adler and Kwon 2002; Molina 2008). Moreover, as a theoretical approach, it shares and is nurtured by several aspects of perspectives linked to the Strategic Management discipline, such as the Intellectual Capital view of the firm, the Knowledge-based view of the firm, the Resource-based view of the firm or the Dynamic Capabilities view of the firm. All these approaches basically explain the value creation of firms from the acquisition/development/building of resources, capabilities, assets or unique knowledge, when they are considered as valuable and unique from an internal perspective. Finally, the theoretical links between social capital and each of these theoretical approaches are explained in this paper. 


\subsection{Social Capital and the Intellectual Capital view of the firm}

Social capital is the sum of the current and potential resources embedded in, available through and derived from the network of relationships, both internal and external, possessed by an individual or a social entity (Nahapiet and Ghoshal 1998; Adler and Kwon 2002). This conceptualization of social capital is similar to that of relational capital, which is a component of the so-called intellectual capital. This is the set of intangible assets of a firm, including elements related to relational, human and organizational aspects (Reed et al. 2006). Specifically, relational capital refers to intangible assets derived from relationships between a firm and its stakeholders, both internal (e.g., employees, shareholders, managers) and external (e.g., customers, investors, suppliers, communities). In general, they are resources and capabilities acquired, created, and developed by a firm resulting from relationships at an individual level (e.g., between employees), group level (e.g., between departments or business units), or organizational level (e.g., between a firm and other agents).

Bueno et al. (2000; 2004) showed the evolution of three main models of intellectual capital generally accepted by academia, with the aim of clarifying the position of social/ relational capital in intellectual capital theories: (1) the Skandia model (Edvinsson and Malone 1997); (2) the Intellect model (Euroforum 1998); and (3) the KMCI (Knowledge Management Consortium International) model. They indicate that the Skandia model follows a more restrictive approach than the other models as it only considers business relationships between agents. In order to overcome this restriction, the Intellect model understands relational capital as being the total value of the array of relationships between the firm and its environment. Nevertheless, it is observed a prominence of indicators concerning relationships with customers, although other aspects such as reputation, strategic alliances, relations with suppliers and links with other agents are also considered by the model. Finally, the KMCI model considers approaches developed by authors such as Nahapiet and Ghoshal (1998), Prusak (1998), Lesser (2000) or Cohen and Prusak (2001), who either revise the concept of relational capital, or replace the concept of relational by social capital.

Specifically, the KMCI model divides relational capital into three categories: (1) intra-social capital; (2) inter-social capital; and (3) social innovation capital. Intra-social capital refers to personal relationships in the firm, established in communities (virtual or physical) that are characterized by relations of an internal nature, and expressing the concept of the organization as community of communities (e.g., Lesser and Prusak 1999; Lesser and Cothrel 2001). Inter-social capital refers to basic relationships of the company with its customers and shareholders. Finally, innovation social capital includes a set of processes and relations that guide the dynamism of the innovative function and that provide the firm with flexibility and capabilities to develop competitive advantages (Bueno et al. 2004, p. 561).

Moreover, the understanding of social/relational capital under the perspective of intellectual capital requires the consideration of the existing links with the remaining elements that integrate the capital intellectual construct (Valverde et al. 2008). Relational capital may thus positively influence the development of human capital (attitudes, abilities, experiences and mental models of members of the organization) and organizational capital (knowledge that is created by, and stored in, systems and technological processes of a 
company). The productive potential of relational capital is based on its capacity to stimulate human resources productivity, as it provides information benefits, or to improve the capacity to generate new applications from the existing knowledge of a firm (Kogut and Zander 1992). In this sense, Subramaniam and Youndt (2005) demonstrated empirically the existence of positive complementarities between relational capital and human and organizational capital. The most noteworthy result of their research was that relational and organizational capital complementarity led to a higher level of development of radical innovation capabilities. Similarly, Reed et al. (2006) tested the hypothesis of relational capital being a complementary resource for human and organizational capital, asserting that the embedded knowledge in internal and external relationships can benefit the rest of the components of intellectual capital and improve the financial performance of the firm (Reed et al. 2006, p. 869).

\subsection{Social Capital and the Knowledge-based view of the firm}

Social capital has also a relevant role in the knowledge-based view of the firm, as it is basically a knowledge-based asset. The Strategic Management literature broadly recognises knowledge as the most prominent resource in the achievement of competitive advantages of all those that a firm can possess or control (Grant 2002).

Authors such as Nahapiet and Ghoshal (1998) state that the most valuable knowledge is embedded in social relations. Hence, if organizations develop high levels of social capital, they will be able to facilitate knowledge development by means of sharing and combining this social capital, and thereby contribute to value generation (Nahapiet and Ghoshal 1998; Tsai and Ghoshal 1998). Furthermore, and from a relational point of view, an organization can create value from generating routines oriented to knowledge sharing with other agents, particularly those which are difficult to imitate or substitute (Dyer and Singh 1998). Moreover, the more developed the social capital of a firm is, the greater is its capacity to access external resources to improve its competitiveness and thus its possibilities of survival ( $\mathrm{Li}$ 2007).

From a different perspective, and considering the ontological dimension of knowledge ${ }^{3}$, it is possible to observe aspects of knowledge revealing similarities with the cognitive dimension of social capital -common codes and communication systems- that would facilitate its transfer between individuals and/or organizations. For example, knowledge sharing within a group needs the development of a shared code and language that allow people to interact, while codification has an essential role for communication between groups, especially when such groups develop dissimilar functions in the organizational ambit (Grant 1996b; Zollo and Winter 2002). Similarly, Kogut and Zander (1992; 1996) point out that, in general, organizations facilitate knowledge transfer by means of a series of "high-order principles", which allow the firm to codify knowledge into a language which is accessible for groups of individuals. Regarding inter-organizational knowledge transfer, these high-order principles are highly relevant as, although they are not specifically detailed,

3 The ontological dimension of knowledge refers to knowledge levels: individual, group -i.e., intra-organizationaland network -i.e., inter-organizational. This distinction is similar to the different levels for which social capital can be analysed. 
they appear to refer to shared codes and values, common communication languages, and so forth (Foss 1996). Such principles would facilitate knowledge transfer form an inter-organizational point of view in a network, as they act as mechanisms by which it is possible to codify technologies into an accessible language to benefit a wider circle of individuals (Kogut and Zander 1992, p. 389-390).

\subsection{Social Capital and the Resource-based view}

The Knowledge based-view could be considered as an extension of the Resource-based view, as knowledge is an intangible resource linked to a firm's competitive advantage (Verde et al. 2008). In this perspective, human and other intangible assets such as technology gain particular relevance (Itami and Roehl 1987; Hall 1993), along with those related to organizational social capital, such as communication and collaborative capabilities, reputation, or culture. Hence, several authors have tried to conceptualize social capital as a set of resources embedded in a firm's relationships (e.g., Loury 1977; Burt 1992). Similarly, Li et al. (2008) suggest that social capital theories may be suitable to understand the usefulness of resources that a company can obtain beyond its organizational limits, especially those based on network approaches.

External relationships can allow a firm to obtain resources in order to gain advantageous positions with respect to competitors (Dyer and Singh 1998; Helfat and Peteraf 2003), although the traditional notion of resources and capabilities as conceived in the literature focuses on the internal aspects of a firm. It should also be considered that social capital can be operationalized and contextualized by specifying different levels of analysis (e.g., individual, group, inter-organizational) (Tsai and Ghoshal 1998). Following Li et al. (2008) and Granovetter $(1985 ;$ 1992), two interrelated perspectives can be used to explain how social capital permits a firm to accumulate valuable resources possessed by other agents, the relational and the structural perspectives of social capital. The main aspects of these perspectives are summarized in Table 4.

On the one hand, the relational perspective considers social capital as an embedded resource in a firm's relationships network (Granovetter 1992). It focuses on the relational aspects of networks and considers the use of interpersonal relationships as being a form of social capital (Lin 2001). In this sense, the relational perspective analyses a company's capabilities to take advantage of dyadic relationships with other agents to obtain specific relational rents (Dyer and Singh 1998; Kale et al. 2000). A relationship between two companies thus builds specific relational capital (Dyer and Singh 1998; Kale et al. 2000), through which the access to real resources such as technology, or to virtual resources such as social status is facilitated ( $\mathrm{Li}$ et al. 2008).

On the other hand, the structural perspective stresses the importance of the relative position of firms in a social structure, which enables them to obtain benefits in terms of information (Coleman 1988; Burt 1992; Uzzi 1997). The characteristics of a network structure depend on the density of the relationships established between the direct contacts of a firm. (Li et al.2008), being the structural root the expression used to describe the structure of the social network (Granovetter 1992; Gulati 1998). A firm's position in the network allows it to access external resources which, by definition, are not sources of competitive advantage as they are easily transferred between firms (Schoemaker and Amit 1993). In this case, it 
is its ability to identify, acquire, integrate and apply resources which enables the firm to generate competitive advantages (Adler and Kwon 2002).

Therefore, social capital is a knowledge-based resource that is generated by a firm from interactions with other agents and permits companies to obtain relational rents by means of the development of valuable, scarce routines which are difficult to imitate or substitute. Additionally, these routines allow the firm to access resources and capabilities of external agents (Dyer and Singh 1998). This second mechanism to generate a competitive advantage is based on the notion of absorptive capacity (Cohen and Levinthal 1990). Both perspectives (structural and relational) establish alternative and complementary ways to achieve and sustain competitive advantages and thus, economic rents based on social capital.

Table 4

Main perspectives of social capital linked to the Resource based-view

\begin{tabular}{|c|c|c|}
\hline & Relational perspective & Structural perspective \\
\hline Intellectual root & $\begin{array}{c}\text { Dyadic social relationships, Re- } \\
\text { source-based view and Transaction Cost } \\
\text { Theory }\end{array}$ & Structure of social relationships \\
\hline
\end{tabular}

Sustained relational rents by means of Theoretical focus value creation and stable relationships with external agents
Information flows, cooperative norms and business success from absorptive capacity
Network structures and structural rooting: identification and acquisition of resources

\begin{tabular}{ccc}
\hline $\begin{array}{c}\text { Main types of } \\
\text { resources }\end{array}$ & $\begin{array}{c}\text { Resources embedded in relational links, } \\
\text { which are valuable, rare, difficult to imi- } \\
\text { tate and non-substitutable }\end{array}$ & $\begin{array}{c}\text { Resources embedded in the position } \\
\text { within the social structure: access to } \\
\text { external resources }\end{array}$ \\
\hline Economic rents & Relational & $\begin{array}{c}\text { Ricardian (control on scarce resources } \\
\text { after integration) }\end{array}$
\end{tabular}

Source: Prepared by the authors from Li et al. (2008).

\subsection{Social Capital and the Dynamic Capabilities-based view}

A noteworthy idea regarding the strategic exploitation of social capital is based on its management over time as a consequence of a continuous search for new business opportunities (Verde et al. 2008). This idea is linked to the Dynamic Capabilities-based view of competitive advantages (see e.g., Teece et al. 1997; Eisenhardt and Martin 2000; Winter 2003; Newbert 2005), which focuses on high-order capabilities (Winter 2003) that allow 
a firm to be able to integrate, build and reconfigure positions of resources, competencies and routines to face environments subjected to continuous change (Teece et al. 1997, Eisenhardt and Martin 2000).

Dynamic capabilities depend on specific assets controlled by a firm, which are eventually responsible for value creation (Teece et al. 1997). Onn the one hand, intangible assets such as brand and reputation can be considered, which are linked to the relational dimension of social capital. These assets could be understood as kinds of indicators for the current firm position and its future behaviour (Donate 2007). On the other hand, there are structural elements referring to both the internal structure of the relations in the firm -formal and informal- and its networks of external relationships linked to the firm's hierarchy, a firm's level of flexibility, or the integration of activities, among others (Teece et al. 1997).

It could thus be concluded that social capital contains elements that may facilitate the development of specific dynamic capabilities, such as those linked to the identification and acquisition of external knowledge. Accordingly, capabilities used to locate and acquire resources within the network might be considered as dynamic capabilities, as they allow a firm to integrate a wide range of resources and expertise into its existing knowledge pool to apply them productively via innovation (Grant 1996a). Economic rents will thus arise when a company, by means of the identification, acquisition and integration of such new knowledge, is able to quickly respond to environmental change (Teece et al. 1997). At the same time, these capabilities will allow a firm to enjoy a temporary monopolistic position, which will eventually disappear due to the imitative effect of its competitors (Schumpeter 1934).

\section{CONCLUSIONS}

The multitude of disciplines and standpoints from which the concept of social capital has been addressed is reflected in the lack of consensus on its definition and dimensions. This research has undertaken the task of developing a review of the way this concept has been considered in the field of organizational studies. From this review, this paper is positioned around the neutral approach to social capital, by adopting the definition proposed by Nahapiet and Ghoshal (1998) and its dimensional disaggregation, since it enables both the intra- and inter-organizational analysis of the concept.

The main objective of this research has thus been to highlight the importance of organizational social capital from a strategic point of view. In this sense, the review of empirical studies has allowed us to confirm that it is possible for companies to use their social capital, both internally and externally to generate value and improve their results and competitiveness. Similarly, the study has confirmed that the theoretical development of social capital is supported by contributions adapted from other theoretical approaches linked to Strategic Management, such as the Approach based on Intellectual Capital, the Knowledge-based Approach, the Resource-based Approach, and the Approach based on Dynamic Capacities.

From the Intellectual Capital-based view, this paper has found similarities between the so-called relational capital within this discipline and the concept of social capital, even though some of the main models of intellectual capital have been established following the perspectives provided by different researchers in that field. 
Similarly, in relation to the Knowledge-based view, the study has shown that social capital is an asset that is generated from knowledge that is present in social relationships. Furthermore, language and shared codes stand out as cognitive aspects of social capital from the ontological dimension of this approach, which would also constitute facilitators of the transfer of knowledge, both inter and intra-organizational level.

Similarly, considering the Resource-based view and taking into account that social capital can be operationalized by different levels of analysis, it has been observed that the resources related to organizational social capital are especially relevant because they allow companies both to generate valuable resources of their own and to gain access to valuable resources of other organizations.

Finally, social capital also contains elements of a relational type that could facilitate the generation of certain dynamic capacities, such as capacities linked to the identification and acquisition of external knowledge, which would allow companies to innovate through adaptation to an increasingly complex and constantly changing competitive environment.

Therefore, it can be concluded that social capital is a resource based on knowledge, which could provide access to other internal or external organizational resources. These resources, used in combination, could constitute sources of competitive advantage and creation of value for companies. Nevertheless, this research is only a preliminary step in the configuration of a comprehensive theoretical framework of each and every one of these disciplines. This first step enables to ascertain that the value creation of a company may be generated through the combination of internal and external areas of organizational social capital. Consequently, future research should be aimed at clarifying and delving further into the different strategic links which unite these approaches, as well as considering their extension to other disciplines of the Social Sciences.

\section{REFERENCES}

Adler, P.S. and Kwon, S.W., 2002. Social Capital. Prospect for a New Concept. Academy of Management Review, 27, 17-40.

Aghamirzaee, T., Tabari M. and Paydar, F., 2014. The Relationship between Social Capital and Knowledge Management in Knowledge-Based Organizations. Management Science Letters, 4, 2469-2478.

Alarcón, J.R., Villaverde, P.M.G., Requena, G.P. and Ortega, M.J.R., 2014. La Capacidad de Absorción como Factor Conductor del Capital Social Cognitivo Hacia la Innovación. Economía Industrial, (391), 33-42.

Andrews, R., 2010. Organizational Social Capital, Structure and Performance. Human Relations, 63 (5), 583-608.

Bellamy, M.A., Ghosh, S. and Hora, M., 2014. The Influence of Supply Network Structure on Firm Innovation. Journal of Operations Management, 32 (6), 357-373.

Bellavitis, C., Filatotchev, I. and Souitaris, V., 2017. The Impact of Investment Networks on Venture Capital Firm Performance: a Contingency Framework. British Journal of Management, 28 (1), 102-119.

Blasco, P., Navas, J.E. and López, P., 2010. El Efecto Mediador del Capital Social sobre los Beneficios de la Empresa. Una Aproximación Teórica. Cuadernos de Estudios Empresariales, 20, 11-34. 
Bolino, M.C., Turnley, W.H. and Bloodgood, J.M., 2002. Citizenship Behaviour and the Creation of Social Capital in Organisation, Academy of Management Review, 27 (4), 505-522.

Bourdieu, P. and Wacquant, L.J., 1992. An Invitation to Reflexive Sociology. Chicago: University of Chicago Press.

Bueno, E., Rodríguez, P. and Salmador, M.P., 2000. Experiencias en Medición del Capital Intelectual en España. El Modelo Intelect. In Bueno, E. and Salmador, M.P. (Eds), Perspectivas sobre Dirección del Conocimiento y Capital Intelectual. Instituto Universitario Euroforum Escorial, 111-121.

Bueno, E., Salmador, M.P. and Rodríguez, O., 2004. The Role of Social Capital in Today's Economy. Empirical Evidence and Proposal of a New Model of Intellectual Capital. Journal of Intellectual Capital, 5 (4), 556-574.

Burt, R.S., 1992. Structural Holes. The Social Structure of Competition. Cambridge MA: Harvard University Press.

Cohen, W.M. and Levinthal, D.A., 1990. Absorptive Capacity. A New Perspective on Learning and Innovation. Administrative Science Quarterly, 35 (1), 128-152.

Cohen, D. and Prusak, L., 2001. Social Capital and Capital Gains in Silicon Valey. In Lesser, E.L. (Ed). Knowledge and Social Capital. Foundations and Applications, Butterworth-Heinemann, 179-200.

Coleman, J.S., 1988. Social Capital in the Creation of Human Capital. American Journal of Sociology, 94, 95-120.

Collins, C.J. and Smith, K.G., 2006. Knowledge Exchange and Combination. The Role of Human Resource Practices in the Performance High-Technology Firms. The Academy of Management Journal, 49 (3), 544-560.

Dakhly, M. and De Clercq, D., 2004. Human Capital, Social Capital and Innovation. A Multi-Country Study. Entrepreneurship \& Regional Development. An International Journal, 16 (2), 107-128.

Delgado, M., Martín, G., Navas, J.E. and Cruz, J., 2011. Capital Social, Capital Relacional e Innovación Tecnológica. Una Aplicación al Sector Manufacturero Español de Alta y Media Tecnología. Cuadernos de Economía y Dirección de la Empresa, 14, 207-221.

Doh, S. and Acs, Z.J., 2010. Innovation and Social Capital. A Cross-Country Investigation. Industry and Innovation, 17 (3), 241-262.

Donate, M.J., 2007. Estrategias de Conocimiento e Innovación. Relaciones y Análisis de sus Efectos en los Resultados Empresariales. Madrid: Consejo Económico y Social, Colección de estudios.

Dyer, J.H. and Singh, H., 1998. The Relational View. Cooperative Strategy and Sources of Interorganizational Competitive Advantage. Academy of Management Review, 23 (4), 660-679.

Ebers, M. and Maurer, I., 2014. Connections Count. How Relational Embeddedness and Relational Empowerment Foster Absorptive Capacity. Research Policy, 43 (2), 318332.

Edvinsson, L. and Malone, M.S., 1997. Intellectual Capital. Realizing Your Company's True Value by Finding Its Hidden Brainpower. New York: HarperCollins Publishers.

Eisenhardt, K. and Martin J., 2000. Dynamic Capabilities. What Are They? Strategic Management Journal, 21, 105-121. 
Euroforum, 1998. El Modelo Intelect. Madrid: Instituto Universitario Euroforum Escorial. Foss, N.J., 1996. Knowledge-Based Approaches to the Theory of the Firm. Some Critical Comments. Organization Science, 7 (5), 470-476.

Gallo, M.T. and Garrido, R., 2009. El Capital Social, ¿Qué Es y Por Qué Importa? Madrid: Serie Ensayos, Instituto Universitario de Análisis Económico y Social.

García, P.M. and Parra G., 2008. Capital Social, Conocimiento y Resultados en los Distritos Industriales. Boletín Económico de ICE, (2948), 53-67.

Gatignon, H., Tushman, M.L., Smith, W. and Anderson, P., 2002. A Structural Approach to Assessing Innovation. Construct Development of Innovation Locus, Type, and Characteristics. Management Science, 48, 1103-1122.

Granovetter, M.S., 1985. Economic Action and Social Structure. The Problem of Embeddedness. American Journal of Sociology, 91, 481-510.

Granovetter, M.S., 1992. Problems of Explanation in Economic Sociology. In Nohria, N. and Eccles, R. (Eds.): Networks and organizations. Structure, form and action. Boston: Harvard Business School Press, 25-56.

Grant, R.M., 1996a. Toward a Knowledge Based Theory of the Firm. Strategic Management Journal, 17 (1), 109-122.

Grant, R.M., 1996b. Prospering in Dynamically-Competitive Environments. Organizational Capability as Knowledge Integration. Organization Science, 7 (4), 375-387.

Grant, R.M., 2002. Contemporary Strategy Analysis. Concepts, Techniques and Applications. Boston. MA: Blackwell Publishers.

Gulati, R., 1998. Alliances and Networks. Strategic Management Journal, 19 (4), 293-317.

Gulati, R., Nohria, N. and Zaheer, A., 2000. Strategic Networks, Strategic Management Journal, 21, 203-215.

Hall, R., 1993. A Framework Linking Intangible Resources and Capabilities to Sustainable Competitive Advantage. Strategic Management Journal, 14 (8), 607-618.

Helfat, C.E. and Peteraf, M.A., 2003. The Dynamic Resource-Based View. Capability Lifecycles. Strategic Management Journal, 24, 997-1010.

Hsu, J.S.C. and Hung, Y.W., 2013. Exploring the Interaction Effects of Social Capital. Information \& Management, 50 (7), 415-430.

Inkpen, A.C. and Tsang, E.W.K., 2005. Social Capital, Networks and Knowledge Transfer. Academy of Management Review, 30 (1), 146-165.

Itami, H. and Roehl, T., 1987. Mobilizing Invisible Assets. Cambridge: Harvard University Press.

Jacobs, J., 1961. The Death and Life of Great American Cities. The Failure of Town Planning. Nueva York: Random House.

Kale, P., Singh, H. and Pelmutter, H., 2000. Learning and Protection of Proprietary Assets in Strategic Alliances. Building Relational Capital. Strategic Management Journal, 21 (3), 217-237.

Kogut, B. and Zander, U., 1992. Knowledge of the Firm, Combinative Capabilities and Replication of Technology. Organization Science, 3 (3), 383-397.

Kogut, B. and Zander, U., 1996. What Firms Do? Coordination, Identity, and Learning. Organization Science, 7 (5), 502-518.

Landry, R., Amara, N. and Lamari, M., 2002. Does Social Capital Determine Innovation? To What Extent? Technological Forecasting and Social Change, 69 (7), 681-701. 
Leana, C.R. and Pil, F.K., 2006. Social Capital and Organizational Performance. Evidence from Urban Public Schools. Organization Science, 17 (3), 353-366.

Lefebvre, V.M., Sorenson, D., Henchion, M. and Gellynck, X., 2016. Social Capital and Knowledge Sharing Performance of Learning Networks. International Journal of Information Management, 36 (4), 570-579.

Lesser, E.L., 2000. Leveraging Social Capital in Organizations. In Lesser E.L. (Ed.): Knowledge and Social Capital. Foundations and Applications. Butterworth-Heinemann, 3-16.

Lesser, E. and Cothrel, J., 2001. Fast Friends. Virtuality and Social Capital. Knowledge Directions, Spring-Summer, 66-79.

Lesser, E. and Prusak, L., 1999. Communities of Practice, Social Capital and Organizational Knowledge. Cambridge, MA: IBM-Institute Knowledge Management.

Li, L., Lin, Z.J. and Aranda, B., 2008. The Turtle-Hare Race Story Revisited. Social Capital and Resource Accumulation for Firm from Emerging Economies. Asia Pacific Journal of Management, 25 (2), 251-275.

Li, P.P., 2007. Social Tie, Social Capital, and Social Behaviour. Toward an Integrative Model of Informal Exchange. Asia Pacific Journal of Management, 24 (2), 227-246.

Lin, N., 2001. Building a Network Theory of Social Capital. In Lin, N., Cook, K. and Burt, R. (Eds.): Social Capital. Theory and Research. New Jersey: Aldine Transaction, 3-29.

Lourand, G., 1977. A Dynamic Theory of Racial Income Differences. In Wallance P.A. and Le Mund, A. (Eds.): Women, Minorities, and Employment Discrimination. Lexington: Max Lexington Books.

Loury, G., 1992. The Economics of Discrimination. Getting to the Core of the Problem. Harvard Journal for African American Public Policy, 1, 91-110.

Martín-Ríos, C. and Septiem, M., 2013. Cooperación e Intercambio de Conocimiento en Redes Inter-Organizativas Informales. REDES-Revista hispana para el análisis de redes sociales, 24 (1), 193-216.

Maula, M., Autio, E. and Murray, G., 2003. Prerequisites for the Creation of Social Capital and Subsequent Knowledge Acquisition in Corporate venture Capital. Venture Capital, 5 (2), 117-134.

Maurer, I., Bartsch, V. and Ebers, M., 2011. The Value of Intra-Organizational Social Capital. How It Fosters Knowledge Transfer, Innovation Performance, and Growth. Organization Studies, 32 (2), 157-185.

Molina, F.X. (Director), 2008. La Estructura y Naturaleza del Capital Social en las Aglomeraciones Territoriales de Empresas: Una Aplicación al Sector Cerámico Español, Madrid: Fundación BBVA.

Moran, P., 2005. Structural vs. Relational Embeddedness. Social Capital and Managerial Performance. Strategic Management Journal, 26 (12), 1129-1151.

Moran, P. and Ghoshal, S., 1996. Value Creation band Firms. In Keys, J.B. and Dosier, L.N. (Eds.): Academy of Management Best Paper Proceedings, August (1), 41-45.

Mu J., Peng, G. and Love, E., 2008. Interfirm Networks, Social Capital, and Knowledge Flow. Journal of Knowledge Management, 12 (4), 86-100.

Nahapiet, J. and Ghoshal, S., 1998. Social Capital, Intellectual Capital and the Organizational Advantage. Academy of Management Review, 23 (2), 242-266. 
Newbert, S.L., 2005. New Firm Formation. A Dynamic Capability Perspective. Journal of Small Business Management, (43), 55-77.

Parra, G., Molina, F.X. and García, P.M., 2010. The Mediating Effect of Cognitive Social Capital on Knowledge Acquisition in Clustered Firms. Growth and Change, 41 (1), 59-84.

Pirolo, L. and Presutti, M., 2010. The Impact of Social Capital on the Start-ups' Performance Growth. Journal of Small Business Management, 48 (2), 197-227.

Portes, A., 1998. Social Capital. Its Origins and Applications in Modern Sociology. Annual Review of Sociology, 24, 1-24.

Preston, D., Chen, D., Swink, M. and Meade, L., 2017. Generating Supplier Benefits through Buyer-Enabled Knowledge Enrichment: A Social Capital Perspective. Decision Sciences, 48 (2), 248-287.

Presutti, M., Boari, C. and Fratocchi, L., 2007. Knowledge Acquisition and the Foreign Development of High-Tech Start-Ups. A Social Capital Approach. International Business Review, 16 (1), 23-46.

Prusak, L., 1998. Presentation to the Conference Board. Conference on Knowledge Management and Organizational Learning. Chicago, IL: April.

Putnam, R. D., 1993. The prosperous community: Social capital and public life, American Prospect, 13, 35-42.

Reed, K.K., Lubatkin, M. and Srinivasan, N., 2006. Proposing and Testing an Intellectual Capital-Based View of the Firm. Journal of Management Studies, 43 (4), 867-893.

Rowleand, T., Behrens, D. and Krackhardt, D., 2000. Redundant Governance Structures. An Analysis of Structural and Relational Embeddedness in the Steel and Semiconductor Industries. Strategic Management Journal, 21, 369-386.

Sanchez-Famoso, V., Maseda, A. e Iturralde, T., 2017. Family involvement in top management team: Impact on relationships between internal social capital and innovation. Journal of Management and Organization, 23 (1), 136-162.

Schoemaker, P.J. and Amit, R., 1993. Investment in Strategic Assets. Industry and Firm-Level Perspectives, Wharton School: SEI Center for Advanced Studies in Management.

Schumpeter, J.A., 1934. Theory of Economic Development. An Enquiry into Profits, Capital, Interest and the Business Cycle. Cambridge, Mass: Harvard University Press.

Smith, K.G., Collins, Ch.J. and Clark, K.D., 2005. Existing Knowledge, Knowledge Creation Capability, and the Rate of New Product Introduction in High-Technology Firms. Academy of Management Journal, 48 (2), 346-357.

Subramaniam, M. and Youndt, M.A., 2005. The Influence of Intellectual Capital on the Types of Innovative Capabilities. Academy of Management Journal, 48 (3), 450-463.

Teece, D.J., Pisano, G. and Shuen, A., 1997. Dynamic Capabilities and Strategic Management. Strategic Management Journal, 18 (7), 509-533.

Tsai, W. and Ghoshal, S., 1998. Social Capital and Value Creation. The Role of Intrafirm Networks. Academy of Management Journal, 41 (4), 464-476.

Tsai, Y.H., Joe, S.W., Ding, C.G. and Lin, C.P., 2013. Modelling Technological Innovation Performance and Its Determinants. An Aspect of Buyer-Seller Social Capital. Technological Forecasting and Social Change, 80 (6), 1211-1221.

Uzzi, B., 1997. Social Structure and Competition in Interfirm Networks. The Paradox of Embeddedness. Administrative Science Quarterly, 35-67. 
Verde, M.D., López, J. E.N., de Castro, G.M. and Sáez, P.L., 2008. Propuesta de un Modelo Teórico sobre el Proceso de Innovación Tecnológica Basado en los Activos Intangibles. Cuadernos de Estudios Empresariales, (18), 203-228.

Wang, M-C. and Chen, M-H., 2016. The More, the Better? The Impact of Closure Collaboration Network and Network Structures on Technology-Based New Ventures' Performance. $R \& D$ Management, 46 (S1), 174-192.

Winter, S.G., 2003. Understanding Dynamic Capabilities. Strategic Management Journal, 24 (10), 991-995.

Yli-Renko, H., Autio, E. and Sapienza, H.J., 2001. Social Capital, Knowledge Acquisition, and Knowledge Exploitation in Young Technology-Based Firms. Strategic Management Journal, 22 (6-7), 587-613.

Yu, S.H., 2013. Social Capital, Absorptive Capability, and Firm Innovation. Technological Forecasting and Social Change, 80 (7), 1261-1270.

Zheng, W., 2010. A Social Capital Perspective of Innovation from Individuals to Nations. Where Is Empirical Literature Directing Us? International Journal of Management Reviews, 12 (2), 151-183.

Zhou, K.Z., Zhang, Q., Sheng, S., Xie, E. and Bao, Y., 2014. Are Relational Ties Always Good for Knowledge Acquisition? Buyer-Supplier Exchanges in China. Journal of Operations Management, 32 (3), 88-98.

Zollo, M. and Winter, S.G., 2002. Deliberate Learning and the Evolution of Dynamic Capabilities. Organization Science, 13 (3), 339-351. 